\title{
Post-Islamism in Indonesia: Analysis of Islamic Political Party Programs in the 2019 National Elections
}

\author{
Gili Argenti ${ }^{1,2}$ \\ Caroline Paskarina ${ }^{2 *}$ \\ Nani Darmayanti ${ }^{3}$ \\ Nandang Alamsah Deliarnoor ${ }^{4}$ \\ ${ }^{1}$ Department of International Relations, Universitas Singaperbangsa, \\ Jl. HS.Ronggo Waluyo, Puseurjaya, Kec. Telukjambe Tim., \\ Kabupaten Karawang, Jawa Barat 41361, Indonesia \\ ${ }^{2}$ Department of Political Science, Universitas Padjadjaran, \\ Jalan Dipati Ukur No. 35, 40132, Bandung, West Java, Indonesia \\ ${ }^{3}$ Department of Indonesia Literature, Universitas Padjadjaran, \\ Jalan Dipati Ukur No. 35, 40132, Bandung, West Java, Indonesia \\ ${ }^{4}$ Department of Governmental Science, Universitas Padjadjaran, \\ Jalan Dipati Ukur No. 35, 40132, Bandung, West Java, Indonesia \\ ${ }^{*}$ Corresponding Author
}

DOI: https://doi.org/10.36941/ajis-2022-0o11

\begin{abstract}
Although most Indonesia's population is Muslim, the Islamic parties' votes do not show a significant general election. This tendency encourages Islamic parties to develop post-Islamism to win the sympathy of majority Muslim voters in Indonesia. Ahead of the 2019 election, identity politics or sectarian politics had strengthened in the 2017 DKI Jakarta Regional Head Election, and even identity politics had long ago emerged with the proliferation of Sharia regulations in several regions, as well as the issuance of the MUI Fatwa regarding the illegitimacy of secularism, liberalism, and pluralism. This study aims to see whether Islamic parties maintain Post Islamism in political programs in the 2019 election. The research uses a library research method by collecting data from books, journals, national print, and online media. The study results explain that Islamic parties remain consistent in using the Post Islamism approach in the 2019 election, even though their vote acquisition is stagnant as a middle board party.
\end{abstract}

Keywords: Post Islamism, Indonesian Islamic parties, the 2019 general election

\section{Introduction}

Contemporary developments regarding political Islam show a shift in ideology, from previously more ideological struggles such as establishing an Islamic state to a more practical political work with welfare, justice, democracy, and equality issues (Bubalo et al., 2008). The phenomenon of the shift in 
political Islam from ideological to pragmatic is called post-Islamism. Post Islamism is different from Islamism, which imposes an Islamic state (Islamic state); post-Islamism still rejects secularism which is hostile to religion and rejects the notion of a theocratic state. Post Islamism is not anti-Islamic and secular and even highly respects religion and the freedom of its citizens. There are three characteristics of post-Islamism, namely (1) its tendency to be pragmatic and realistic, (2) its willingness to compromise with political realities that do not entirely deal with the Islamic ideological scheme they believe in and imagine, and (3) it is very tolerant with different groups (Bayat, 2011).

Islamism is an understanding of returning to the original principles of religion, namely that Islamic rules do not touch any aspect of life. The concept of Islamism is a global movement that seeks to create an Islamic state or theocracy through contestation in a democratic system (Soekanto, 2016).

Post Islamism as a socio-political phenomenon signifies the change of political Islam movement from ideological to pragmatic, which has become mainstream in Islamic countries such as Malaysia, Turkey, and Tunisia. In Malaysia, the All-Malay Islamic Party $(P A S)$ has moderated its movement; $P A S$ political program is designed more universally than before, such as egalitarianism, tolerance, and accommodation of minority groups. PAS campaign rhetoric has also separated religion from ethnicity; even in the 2008 election, PAS collaborated with two nationalist parties (DKP and PKR) by jointly bringing up justice, good governance, and human rights issues (Muda, 2016). In Turkey, the AKP (Adalet ve Kalkinma Partisi) Erdogan's party assured the public that they were not promoting Islamism or establishing an Islamic state. The $A K P$ is fighting for economic prosperity, political freedom, and social equality (Taufiq, 2020). The $A K P^{\prime}$ s victory in every election is followed by the party's commitment to maintaining the values of Turkish secularism. The AKP does not exploit religious issues for political ambition and chooses to follow the political direction proclaimed by Mustafa Kemal Ataturk, namely establishing a modern Turkish society. The $A K P^{\prime}$ s political actions have always favored the people's decisions and did not want a dispute with the Kemalist military (Taghian, 2011). The AKP believes that the democratic system can be compatible with Islam; here, the term Muslim democrat is commonly used (Alfian, 2015).

Meanwhile, in Tunisia, the Islamist party, the Ennahdha Party, in 2016, declared itself an open party; by separating religious and political affairs, the previously attached da'wah activities were stopped as a means of uniting, not creating division and division. Ennahdha's choice became open because, before the Arab Spring, all movement activities had been carried out in secret. However, after the revolution in which the era of openness and democracy was adopted into the Tunisian political system, the party's activities must be open, no longer using religion for political purposes. The Ennahdha Party, in its political program, does not aspire to an Islamic state; this party concentrates on creating a secular Tunisian republic (Ghannouchi, 2020). The political moderation of the Ennahdha Party is one of the keys to the democratic transition in Tunisia that runs well after the Arab Spring, not trapped in conflicts between Islamist and secular groups like in Egypt, which led to a coup (Sahide, 2019).

In Indonesia, the most prominent Islamic country globally, Islam is placed not only as a religion but in practice; Islam has also become an ideology of resistance in opposing colonialism and western imperialism (Fogg, 2020). After Dutch colonialism, Islam has a strategic role as a political ideology for Islamic parties such as the Masyumi Party and the Nahdatul Ulama Party (NU). These two Islamic parties are very ideological, and they consistently fight for Islam as the basis of the state in the constituent institutions. As an institution tasked with drafting and enacting a new constitution to replace the 1950 Constitution, the Constituent Assembly convened from 1956-1959 (Madiner, 2013).

The trial in the Constituent Assembly was very tough, especially when discussing the basis of the state. The discussion ended in ideological polarization involving three political forces, namely nationalist, Islamist, and socio-economic groups. The ideological struggle is quite fierce between the nationalist and Islamic groups; these two groups have different political ideas regarding the basis of the state. The Islamic group wants Islam to be the basis of the state, while the nationalist group wants the state basis of Pancasila (Kamil, 2013). Both groups have the same number of votes in the 
constituency so that every voting is carried out. No group can reach $2 / 3$ of the vote, meaning that the decision based on the state is not reached unanimously. As a result, this institution is considered to have failed in completing its tasks. Then through a Presidential Decree of July 5, 1959, the constituent body was dissolved (Gaffar, 2001).

During the New Order era, the political influence of the sects decreased. This decrease was in line with President Soeharto's policy of depoliticizing politics so that the political ideology of Islamic groups weakened (Hanan, 2002). The New Order government succeeded in forcing the fusion or merging of Islamic parties into one party, namely the United Development Party (PPP) (Mahfiz, 2011). After the New Order succeeded in imposing the fusion of Islamic parties, the following policy of the government in controlling political Islam and establishing the single principle of Pancasila in 1985, this single principle policy has killed the aspirations of political Islam groups in establishing an Islamic state (Matta, 2006). The New Order's increasingly repressive policies eventually made the influence of political Islam groups dim. The dimming of this group gave birth to a new group, namely cultural Islam, one of which was Nurcholish Madjid. The emergence of cultural Islam is an alternative when the state is hostile to political Islam. The well-known jargon of this group is 'Islam Yes, Islamic Party No' (Matta, 2006). The substance of Islam is more highlighted by cultural Islam than the issue of power. Islamic cultural groups want the face of Islam to be more tolerant and dynamic. The cultural groups developed Islam following the development of modern society, based on scientific, not an ideological-symbolic one. Because ideological preference is very dangerous, it is closed, in contrast, to open cultural appreciation, and this group has no desire to make Islam the basis of the state (Azra, 2020).

After the fall of the New Order government in 1998, Indonesia entered an era of openness or democratization, a period marked by the freedom to establish political parties. Since then, amidst the emergence of dozens of political parties that stood at the beginning of the reform, there were Islamic parties, including the United Development Party (Partai Persatuan Pembangunan or PPP), the National Awakening Party (Partai Kebangkitan Bangsa or PKB), the National Mandate Party (Partai Amanat Nasional or PAN), the Prosperous Justice Party (Partai Keadilan Sejahtera or PKS), and the Crescent Star Party (Partai Bulan Bintang or PBB) (Al-Hamdi, 2013). The five Islamic parties still exist today and even have representatives in the executive and legislative bodies, from the central to the regional levels. These five Islamic parties could maintain popular votes in the election from 1999 to 2014, which was assumed by their ability to adapt politically, from Islamist to post-Islamist or from formalist to substance. The ideological shift of Islamic parties follows the behavioral trend of Indonesian Muslim voters who do not like ideological symbols. Muslim voters today are increasingly rational and independent. Idealistic and ideological considerations in choosing political parties are no longer dominant. This tendency indicates a trend of political struggle towards an opportunist rather than ideological direction; even developments after the 1990s increasingly show the waning of political flow due to socio-religious changes due to increased education and economic mobility.

However, before the 2019 National Election, Indonesia's political atmosphere is inversely proportional to the previous periods. This indication is shown in the 2017 DKI Jakarta Gubernatorial Election. The competition between Basuki Tjahaja Purnama and Anies Baswedan is robust in political flow and populism, where minority groups and non-Muslims strengthened. The meaning of populism itself does not believe in pluralism, rejects the complexity in society, and has anti-elite tendencies (Velasco, 2020). Interrelated identity politics support the presence of populism; identity politics is related to the struggle for power based on ethnic and religious identities (Buchari, 2014). The reinvigoration of identity politics reminds the Indonesian public of the current politics of the parliamentary democracy (Old Order). In addition to the thick identity politics ahead of the 2019 National Election, even the earlier few years showed a trend of changing the religious orientation of the Indonesian Muslim middle class, from being open to being more conservative, demonstrated by the strong support for sharia regulations in several regions, as well as the issuance of fatwas.

Contrary to Islam, the Indonesian Ulema Council (MUI) regards secularism, pluralism, and liberalism (Bruinesse, 2014). Therefore, this study looks at how Islamic parties in Indonesia narrate 
their political ideology in the 2019 National Election, whether they return to the ideological-formalist political forces or remain a post-Islamist-substance group. To analyze the Islamist or post-Islamist category, the authors see it from the political program of Islamic parties during the campaign period in the 2019 General Election, which was published in several mainstream media in Indonesia.

\section{Literature Review}

Political Islam in Indonesia is getting weaker. Public support for Islamic parties fluctuates from election to election, as shown in the acquisition of Islamic parties in each election: 1999 election (36.7\%), 2004 election (38.3\%), 2009 election (29.2\%), and 2014 (31.4\%). Although there was an increase in the number of elections, namely in 1999, 2004, and 2014, the increase was not significant; in fact, the vote was still far from the Masyumi Islamic Party (43.5\%) in the General Election 1955 (Wahyu, 2021).

A study shows that three factors weaken public support for Islamic parties, namely (1) Indonesian people have made Pancasila a shared national commitment, (2) internal political divisions within Muslims so that the synergy of the movement is not optimal, and (3) the inability of the Islamic parties in solving real problems that occur in society, such as the issue of poverty, and unemployment. Therefore, Islamic parties must understand the political culture in Indonesian society and improve their services to the people (Yumitro, 2013).

Another study explains that the development of Islamic parties in the reform era is far more in quantity than the number of Islamic parties during the Old Order era, specifically parliamentary democracy. Still, when viewed in each election, the number of votes has consistently decreased. Several factors cause Islamic parties to fail to win the support of Muslim voters, such as the emergence of internal conflicts, e.q. the split within $P P P$, which gave birth to the Reform Star Party, and management conflicts within the $P K B$ for several periods. Another factor is the establishment of Islamic organizations by nationalist parties to accommodate groups of students. For example, the Indonesian Democratic Party of Struggle (PDI-P) establishes Baitul Muslimin; the Democratic Party has a Coordination Board for Gathering Ulama, and Umaroh (Bakosiru) Golkar Party has a Recitation of Al-Hidayah. The party leadership crisis is seen from the scarcity of popular figures or figures accepted by all circles. Thus, Islamic parties must pay more attention to welfare programs, democratization, eradicating corruption, and realizing social justice (Romli, 2020).

Subsequent studies explain the process of Islamization in all lines of Muslim life in Indonesia since the reform era, from the hijab phenomenon in public spaces, the proliferation of recitations in big cities, Islamic applications on smartphones, and the proliferation of Islamic films in cinemas. However, according to this study, this Islamic phenomenon is not directly proportional to the vote gains of Islamic parties, especially in the 2009 General Election. The study also explains that Indonesian voters generally prefer economic and anti-corruption issues in the 2009 election rather than morality and religion. However, the issue of morality and religion does not mean that it is not essential, only that the attention of Indonesian voters does not make it a primary factor when voting in the 2009 General Election (Herdiansah, 2017).

The following study explains the decision to become ideological or pragmatic from Islamic parties after the New Order is rationalized. Actions were taken to consider the orientation of political interests and maintain Islamic political parties' identity (positioning) during elections. In 2001, after the impeachment of President Abdurrahman Wahid and later on succeeded by Megawati Sukarnoputri, the Islamic parties that joined the center axis finally accepted women's leadership, as evidenced by the inclusion of cadres from Islamic parties into the government cabinet. This Islamic party ideologically rejects women's political leadership. In 2002, $P P P$ and $P B B$ tried to revive the Jakarta Charter. At first glance, the actions of the two parties seemed ideological, when in fact, the strategy was to reach voters who had the same ideological vision or identity in the next election. Likewise, in the 2009 and 2014 elections, when Susilo Bambang Yudhoyono (SBY) from the nationalist group won successively, Islamic parties could always be loyal government supporters. 
Apart from giving the impression of showing a pragmatic face, ideological discourses occasionally appear, for example, the PPP tagline in the 2014 election voicing the slogan "House of the Muslims" to ensure that they are still consistent in bringing up public issues. Similarly, the attitude of $P K S$ after the 2014 election, which took the option of being outside the Jokowi government, the choice to become an opposition was due to the strong desire of cadres for PKS to withdraw from government circles; this phenomenon shows the ideological option of VFD. However, this study does not explain the position of Islamic parties ahead of the 2019 General Election (Herdiansah, 2017).

An insightful study was conducted on the development of contemporary political Islam in Indonesia, namely the coalition of Islamic parties in the 2019 Presidential and Vice-Presidential Elections. In the 2019 Presidential Election, two pairs of candidates participated. The first pair is Ir. Joko Widodo-KH. and Maruf Amien who was promoted by PDI P, Golkar Party, Nasdem Party, Hanura Party, $P K B$, and $P P P$. In addition, the pair also received support from political parties that do not have seats in parliament, namely PSI, PBB, Perindo, and PKPI. The second pair is the Prabowo Subianto-Sandiaga Salahuddin Uno coalition. This coalition is supported by the Gerindra Party, PAN, $P K S$, and the Democratic Party. Prabowo has strong support from modern Muslim movements such as Alumni 212, while Jokowi has the help of the enormous Islamic mass organization Nahdlatul Ulama $(N U)$. Islamic parties should carry their partners in the 2019 election, meaning that all Islamic parties have a stronger victory orientation than ideological orientation in forming coalitions. Islamic parties such as $P K B$ and $P P P$ have long claimed to support Jokowi, while PKS supported Prabowo. Later, PAN emerged, which also helped Prabowo (Addiansyah, 2019).

\section{Theoretical Framework}

The formation of an Islamic party does not conflict with the principles of democracy in Indonesia. Each group is recognized to form an organization of political power following its aspirations and interests. This practice is also supported by the legislation in which there is no prohibition against creating political parties based on religion as long as it does not conflict with Pancasila (Romli, 2020). Discourse on Islam and politics is still a hot topic; scholars of Islam and politics have concluded that at least three schools of thought explain the relationship between Islam and politics. The three schools of thought are Islamic formalism (union of Islam and politics), Islamic substantialism (Islamic ethics in politics), and secularism (strict separation of Islam and politics). Among the three schools of thought, one is equally influential and has followers in the Indonesian Muslim community (Qodir, 2012).

Islamic formalism has the view that the establishment of an Islamic state is an obligation. This first group model does not recognize the separation between religion and politics; according to them, the idea of separating the divine and the worldly aspects is absurd. The function of the state must be the servant of religion. Hence, the concept of secularism has no place for this group. In contrast, the Islamic substantialist groups have different views on the flow of Islamic formalism. Supporters of this second model have religious beliefs that are neutral in state politics. They have two main foundations: the Pancasila ideology accepted as the basis of the state and resistance to secularism. Islamic values can be practiced in state life for the essential Islamic substantialist group, such as justice, welfare, and equality. They reject the form of an Islamic state. Finally, Islamic secularists believe that a good function of the state does not interfere with various religious problems of its citizens; the state must minimize interference in the private affairs of its people. Supporters of the third model place the state as a public institution that belongs to every citizen. The form must be neutral; the third model also criticizes some Muslims who continue to demand an Islamic state in Indonesia (Assyaukanie, 2011).

To explain the shift in the ideological orientation of Islamic parties in Indonesia from ideological-formalist issues to substantive-pragmatic issues in the political program in the 2019 National Election campaign, the authors use rational choice theory, which departs from an assumption of maximizing profits. In this theory, society is seen as an actor who acts rationally to 
achieve their interests (Mueller, 1979).

In the rational choice model of political relations that occur like logic in the market, two parties maximize profits between producers and consumers. Political parties finally position themselves based on producers, namely being in a position where most consumers are. As a result, political parties become vote-seeking parties. Political institutions no longer maintain a specific political program or persist with their ideological identity but try to create policies or political agendas. The goal is to get as much support as possible from all groups or social strata in society. Despite this political act, one must abandon the ideology and characteristics of the party's identity, from ideological to pragmatic at first (Wolinetz, 2002).

Political relations in the rational choice model are usually political parties that will try to approach the characteristics of the voters by taking a position following the will of the majority voters; the aim is to maximize vote support from voters in elections. They will undoubtedly vote for political parties that have the closest preferences to themselves for the voters themselves. On the other hand, political parties will try to present themselves as parties that reflect the wishes or desires of the voters, even though this act marginalizes their ideological beliefs (Kleden, 2005).

\section{Methods}

The methodological approach used in this study uses a qualitative approach. The qualitative approach intends to understand phenomena through descriptions in words and language (Gunawan, 2013). The data collection method is based on the study of literature (library research). Library research is a way to extract data from books, journals, magazines, newspapers, laws, websites, and other written data relevant to the discussion.

The authors collect data and then analyze these sources by breaking them into sequences, patterns, and data categorization in predetermined aspects according to the intent and focus of the research question. The data were analyzed systematically, the discussion focused on the political program of Islamic parties in the 2019 National Election, while the Islamic parties that became the topic of this research were the United Development Party $(P P P)$, the National Awakening Party $(P K B)$, the National Mandate Party $(P A N)$, the Prosperous Justice Party $(P K S)$, and the Crescent Star Party $(P B B)$.

\section{Result and Discussion}

The United Development Party $(P P P)$ is a political party resulting from a fusion of four Islamic political parties inherited from the Old Order government: the Nahdatul Ulama Party (NU), the Indonesian Islamic Union Party (PSII), the Indonesian Tarbiyah Party (Perti) and the Indonesian Muslim Party (Partai Muslimin Indonesia/Parmusi) (Qodir, 2012). In the party's articles of association, $P P P$ has five objectives: (1) implementing Islamic teachings in individuals, society, nation, and state; (2) encouraging to create the best possible climate for implementing worship activities according to Islamic law; (3) fostering ukhuwah Islamiyah to strengthen the unity and integrity of the Indonesian nation in social and state activities; (4) cooperating with political parties and other groups to achieve common goals based on tolerance and mutual respect; and (5) eradicating the notion of communism (atheism) and other ideas that are contrary to Islamic law (Qodir, 2012).

In the 2019 National Election, PPP targets to be in the top three by implementing the $P P P$ Winning Trilogy strategy. The strategy is implemented by the National Election Winning Body (Bappilu), which consists of three steps. First, PPP will retain 39 seats from 39 electoral districts that $P P P$ won in the 2014 election. Second, PPP will take back the seats it won in the 1999 and 2004 elections. These two winning steps are easier to realize by changing PPP from a rigid or Islamist ideology to a friendly party to a broader circle of people. Third, targeting votes from youth voters or millennial groups. To realize the Trilogy of Victory, $P P P$ created the tagline 'Move with the People' by presenting itself as a populist, moderate, and Mondial Islamic party (REK, 2016). The PPP tagline in 
the 2019 election is very different from the previous one in the 2014 election, which had the tagline "The Big House of the Muslims" shift in ideological orientation from Islamist to Post Islamist (Osa \& Hernowo, 2014).

The PPP programs offered in the 2019 election include assistance for the construction of Alsintan (agricultural machinery) for farmers and fishing facilities and infrastructure for fishers. Another program is to increase the number of recipients and the number of funds for the Family Hope Program $(P K H)$ from IDR 1,890,ooo per year to IDR 3,780,00o per year. The number of recipients rose to 28 million families from the previous 10 million families. $P P P$ also fights for the government to increase loans without collateral for the Fostering a Prosperous Family Economy (Mekaar) program from IDR 2 million to IDR 5 million (Putri, 2019). From several PPP programs, it can be seen that this party makes the economy the main issue. Even though its ideology is Islam, its political program is far from identity politics, especially in this 2019 election. $P P P$ is part of the coalition carrying Ir. Joko Widodo-KH. Maruf Amien, partner of the nationalist PDI-P defense party. The momentum of strengthening identity politics in the 2017 regional election (Pilkada) could be $P P P^{\prime}$ s momentum to increase its electability. $P P P^{\prime}$ s identity as an Islamic party could be an added value, especially since this party has had a place in the hearts of Muslim voters since the New Order era (Saputra, 2019).

Even though scholars founded the National Awakening Party $(P K B)$, this party was designed as an open Islamic party that upholds the Indonesian nation's principle of diversity or pluralism. $P K B$ is a party that was born from Nahdlatul Ulama $(N U)$, an Islamic social organization that adheres to the ahlussunnah wal Jama'ah or aswaja understanding. Contact with $N U$ makes $P K B$ to be identified as the nahdliyin party or the santri party. Ideologically, $P K B$ does not stipulate Islam as its principle but instead establishes the principle of Pancasila. $P K B$ is still included as an Islamic party because this party has a support base from Islamic organizations. According to the $P K B$, Islam does not have to be standardized or formalized to benefit exclusive groups, as if it is a differentiating tool from other groups. Still, in a country like Indonesia, Islamic teachings will be nobler if they are transformed into a source of values that protect and mobilize people's resources and other components of the nation to realize social justice, prosperity, and independence. $P K B$ identifies itself as a religious humanist party by prioritizing the struggle to return people's sovereignty, justice, and unity. In its statute, $P K B$ declares itself as an open party.

In the 2019 National Election, $P K B$ targets 12-15 percent of the vote, with the big theme "Indonesia Maju Lahir Batin or Indonesia is Progressing." This theme is a combination of PKB campaign themes in the 2014 election, "Indonesia is Progressing," and the 2019 Jokowi-Amin campaign theme was also similar to that theme. The theme is then elaborated in several pragmatic political programs. In the economic field, $P K B$ offers to strengthen the village economy by increasing village funds from the $A P B N$. From the current allocation of IDR 1 billion to IDR 2 billion per village, $P K B$ allocates up to IDR 4 billion per village. While in the political field, $P K B$ wants to offer to strengthen the consolidation of democracy.

The National Mandate Party $(P A N)$ is an Islamic mass-based party founded by Amien Rais (Former Chairman of PP Muhammadiyah). On August 23, 1998, PAN was declared at Istora Senayan Jakarta, attended by around 15 thousand people. The party bearing the sun logo establishes its mass base from modernist Islam (Muhammadiyah). Even though it is based on urban Muslims, PAN expresses itself as an open party using the Pancasila principle, which respects pluralism, pluralism, and social justice. This party consists of Indonesian citizens from various backgrounds in terms of thought, ethnicity, and religion.

The purpose of establishing $P A N$ is to uphold people's sovereignty, justice, material, and spiritual progress. Thus, the ideals of PAN are to create a democratic state life, where the highest state power is in the hands of the people (Amir, 2003). As a political party that emerged in the reform momentum, $P A N$ represents the spirit of renewal, openness, and pluralism. During the reform era elections, $P A N$ 's votes tended to stagnate. The highest percentage of votes was won in the 2004 elections, with 9.6 percent of the valid national ballots. However, in the 2009 General Election, this 
achievement fell to 6 percent and slightly increased in the 2014 election (7.6 percent) (Marsyukrilla, 2019).

However, on each election, $P A N$ is increasingly presenting itself as a party based on a particular religion rather than an open party due to the centralization of power in the figure of Amien Rais, who is aggressively voicing issues based on identity politics. The tendency of PAN to crystallize as a party stream is increasingly being felt by various groups, both party supporters and parties outside the party. The image of PAN as an open party, home to all groups, religions, and ethnicities, is fading (Suryaningtyas, 2019).

Being aware of the unfavorable political position because it is too symbolic-ideological, finally, in the 2019 National Election, this party took a pragmatic strategy. During the election campaign, $P A N$ tried to renew its image to become more dynamic and plural by attracting many young artists to become candidates. Members of the legislature and overhauling party management include more young cadres (Suryaningtyas, 2019).

The Prosperous Justice Party $(P K S)$, previously known as the Justice Party $(P K)$, is a political party pioneered by young Islamic figures. On July 20, 1998, this party was declared and confirmed as a party based on Islam (Damanik, 2002). The political goals of PKS are: to build a just and prosperous Islamic-based civil society (religious-based civil society) within the framework of the Unitary State of the Republic of Indonesia (NKRI), civil society that is a highly civilized and advanced society based on values, norms, laws, morals that are supported by faith, respect plurality, be open and democratic, and work together to maintain state sovereignty (Qodir, 2013).

The 2004 General Election became the momentum for PKS to establish itself as a respected Islamic party. Armed with 8,149,457 votes, $P K S$ seated 45 of its cadres as members of the DPR. In the 2009 election, $P K S$ won 8,204,946 valid national votes and placed 57 of its party cadres in parliament. $P K S$ 's vote gain was consistent until the 2014 General Election in the range of 8 million voters. In the 2014 election, $P K S$ won 8,480,204 votes and placed 40 cadres in parliament (Yuniarto, 2019). PKS's peculiarity from other Islamic parties is built based on ideological strength and solid cadre. The main strength of $P K S$ lies in the ideological power inherent in each cadre. This ideological and cadre strength became the basis for widening the penetration of PKS electoral politics (Nainggolan, 2019).

Even though it is a very ideological party, $P K S$ always offers a pragmatic political program and never raises the constitutional application of Islamic law. Instead, this party campaigns for clean, caring, and professional slogans and emphasizes secular issues such as the fight against corruption, good governance, and socio-economic equality (Muhtadi, 2012). In the 2019 election, PKS offered four political programs, namely (1) valid driving license (SIM) for life, (2) free vehicle tax, (3) tax-free for citizens with income below IDR 8 million, and (4) bill of protection clergy and religious symbols (Saputro \& Mabruroh, 2019). Of the four political programs offered by PKS to the public, the three programs reflect political pragmatism. There is only one program that is considered to have religious nuances of identity politics. Still, if we go deeper into this fourth point, it is general to all religions, so it is not specific to Islamic groups.

The Crescent Star Party $(P B B)$ was declared on June 17, 1998. However, the embryo of the formation of this party can be traced back to 1989, when several prominent Islamic organizations formed the BKUI (Coordination Body for Muslims). This institution became a forum for Muslim leaders to discuss various social and national issues (Novianto \& $\mathrm{Al}, 1999$ ). The United Nations believes that Islam is a religion and a way of life. Islam is seen as a universal religion of rahmatan lilalamin, so in that context, the United Nations considers it necessary to include Islam as the principle and creed of the party. According to the United Nations, based on Islam, you must genuinely believe in the greatness of Islam as a religion that was revealed to bring humanity out of an atmosphere of darkness into an atmosphere of true light. Every word, thought, and action of the party is always based on universal Islamic teachings. The United Nations Islamic teachings are a source of inspiration, motivation, and law in human life (Amir, 2003).

In the 2014 election, the UN could not meet the parliamentary threshold of 3.5 percent of the valid national vote. In the 2019 election, the United Nations faced fierce contestation. The number of 
parties competing for voter votes is more, namely 16 political parties from the previous 12 national political parties. In addition, the parliamentary threshold rose from 3.5 percent in the 2014 election to 4 percent in the 2019 election (Purwanto, 2019). To increase its electability in the 2019 election, the United Nations prepared various breakthroughs to gain voter support. One of them is to distribute 20 million stickers throughout Indonesia to win the sympathy of voters. The United Nations also focuses on defending the community. Abroad, the United Nations builds strength by helping Indonesian workers solve their cases (Rita, 2019). In the Presidential Election in 2019, the UN anchored its support to the nationalist group Ir. Joko Widodo-Ma'ruf Amin (Rita, 2019).

\section{Conclusion}

Islamic and mass-based Islamic parties in the 2019 elections took a moderation and pragmatic approach. They do not make ideological issues the main narrative in politics because these five Islamic parties know that Indonesian voters do not like ideological symbols.

Political programs from Islamic parties are no longer based on religious and ideological interests. Islamic parties in Indonesia now tend to be pragmatic in politics. This fact makes Islamic parties prefer to pursue power rather than a benefit. Ironically, even though they are post-Islamists, Islamic parties still occupy the middle board in electoral contestation. The results of the 2019 National Election show the Indonesian Democratic Party of Struggle (PDI-P) and the Indonesian People's Movement Party (Gerinda), both of which are not Islamic parties, to win the 2019 National Election.

\section{Acknowledgment}

This research is conducted in conjunction with funding received from the Ministry of Research and Technology/National Research and Innovation Agency of the Republic of Indonesia (2021) for research entitled "The Contestation of Political Ideology in Jamaah Tarbiyah (Discourse Analysis on the Idea of Open Political Party in Partai Keadilan Sejahtera, Gerakan Arah Baru Indonesia, and Partai Gelombang Rakyat Indonesia." Grant number: 1207/UN6.3.1/PT.oo/2021.

\section{Reference}

Addiansyah, M. N. R. (2019). Koalisi Partai Politik Islam pada Pilpres 2019: Antara Ideologis dan Pragmatis. POLITEA Jurnal Pemikiran Politik Islam, 2(2).

Al-Hamdi, R. (2013). Partai Politik Islam Teori dan Praktik di Indonesia. Graha Ilmu.

Alfian, M. A. (2015). Militer dan Politik Turki: Pergeseran Politik dan Terpinggirnya Militer Pasca AKP. Penerbit PT Penjuru Ilmu Sejati.

Amir, Z. A. (2003). Peta Islam Politik Pasca Soeharto. LP3ES.

Assyaukanie, L. (2011). Ideologi Islam dan Utopia: Tiga Model Negara Demokrasi di Indonesia. Freedom Institute.

Azra, A. (2020). Menjaga Indonesia dari Kebangsaan hingga Masa Depan Politik Islam. Kencana.

Bayat, A. (2011). Pos Islamisme. LKIS.

Bruinesse, M. van. (2014). Conservatif Turn: Islam Indonesia dalam Ancaman Fundamentalisme. Mizan.

Bubalo, A., Fealy, G., \& Whit, M. (2008). Zealous Democrats: Islamism and Democracy in Egypt, Indonesia, and Turkey. Lowy Institute for International Policy.

Buchari, S. A. (2014). Kebangkitan Etnis menuju Politik Identitas. YOI.

Damanik, A. S. (2002). Fenomena Partai Keadilan: Transformasi 20 Tahun Gerakan Tarbiyah di Indonesia. Teraju.

Fogg, K. W. (2020). Indonesia's Islamic Revolution. Cambridge University Press, University Printing House.

Gaffar, A. (2001). Politik Indonesia: Transisi menuju Demokrasi. Pustakan Pelajar.

Ghannouchi, R. (2020). Siasat Muslim Demokrat di Arah Baru (Y. Maulana (Ed.)). Penerbit Yayasan Faham Mandiri.

Gunawan, I. (2013). Metode Penelitian Kualitatif Teori dan Praktik. Bumi Aksara.

Hanan, D. (2002). Gerakan Pelajar Islam di Bawah Bayang-Bayang Negara: Studi Kasus Pelajar Islam Tahun 19801997. UII Press. 
Herdiansah, A. G. (2017). Pragmatisme Partai Islam di Indonesia: Pendekatan Tindakan Sosial. SOSIOGLOBAL: Jurnal Pemikiran Dan Penelitian Sosiologi, 1(2).

Kamil, S. (2013). Islam dan Politik di Indonesia Terkini: Islam dan Negara, Dakwah dan Politik, HMI, Anti Korupsi, Demokrasi, NII, MMI, dan Perda Syariah. PSIA UIN Jakarta.

Kleden, P. (2005). Menuju Tengah Baru: Labour Party Inggris dam SPD Jerman di Bawah Tekanan Neoliberalisme. Pustaka Pelajar.

Madiner, R. (2013). Partai Masjumi: Antara Godaan Demokrasi dan Islam Integral. Penerbit Mizan.

Mahfiz, I. C. (2011). Islam, Nasionalisme, dan Masa Depan Negara-Bangsa Indonesia Pandangan Para Ahli dan Aktifis Islam. Fraksi Partai Persatuan Pembangunan.

Marsyukrilla, E. (2019, April 9). Partai Amanat Nasional: Lahir dari Reformasi. Harian Kompas.

Matta, A. (2006). Dari Gerakan ke Negara: Sebuah Rekontruksi Negara Madinah yang Dibangun dari Bahan Dasar Sebuah Gerakan. Fitrah Rabbani.

Muda, W. A. F. B. W. (2016). Pemikiran Pasca Islamisme dalam Konteks Gerakan Islam di Malaysia. International Journal of Islamic and Civilizational Studies, 3(3).

Mueller, D. C. (1979). Public Choice. Cambridge University Press.

Muhtadi, B. (2012). Dilema PKS: Suara dan Syariah. KPG.

Nainggolan, B. (2019, October 11). Buah Kesetiaan Politik PKS. Harian Kompas.

Novianto, K., \& Al, C. (1999). Era Baru Indonesia: Sosialisasi Pemikiran Amien Rais, Hamzah Haz, Matori Abdul Djalil, Nur Mahmudi dan Yusril Izha Mahendra. Rajawali Press.

Osa, S., \& Hernowo, M. (2014, January 24). Partai Persatuan Pembangunan: Suryadarma Ali, Rumah Besar Umat Islam. Harian Kompas.

Pemilih Muslim Semakin Independen. (2014, March 17). Harian Republika.

Purwanto, A. (2019, April 12). Partai Bulan Bintang: Penerus Jalan dan Semangat Masyumi. Harian Kompas.

Putri, N. N. (2019). PPP Luncurkan 10 Program Pro Rakyat. Detiknews.Com. https://news.detik.com/berita/d4447639/ppp-luncurkan-10-program-pro-rakyat

Qodir, Z. (2012). Sosiologi Politik Islam: Kontestasi Islam Politik dan Demokrasi Islam. Pustaka Pelajar.

Qodir, Z. (2013). HTI dan PKS Menuai Kritik: Perilaku Gerakan Islam Politik Indonesia. JKSG.

REK. (2016, June 6). Partai Politik: PPP Targetkan Masuk Tiga Besar. Harian Kompas.

Rita, S. (2019, April 12). Loyalitas yang Tidak Redup. Harian Kompas.

Romli, L. (2020). Electoral Power Structure of Islamic Parties in Reform Era Indonesia. Politik Indonesia: Indonesian Political Science Review, 5(2), 192-213.

Sahide, A. (2019). The Arab Spring: Tantangan dan Harapan Demokratisasi. Penerbit Kompas.

Saputra, A. T. D. (2019). Pergolakan Partai Islam di Tahun Politik. Yayasan Pustaka Obor Indonesia.

Saputro, F. A., \& Mabruroh. (2019). Mengapa Suara PKB dan PKS Naik Signifikan di Pemilu 2019? Nasional. Republika. Co. Id. https://nasional.republika.co.id/berita/nasional/news-analysis/pq8rbe44o/mengapasuara-pkb-dan-pks-naik-signifikan-di-pemilu-2019

Soekanto, S. S. (2016). Strategi Pemenangan Pemilu AKP di Turki dan PKS di Indonesia Studi Perbandingan. Universitas Indonesia Press.

Suryaningtyas, T. (2019, October 17). Upaya PAN Keluar dari Stagnasi. Harian Kompas.

Taghian, S. (2011). Erdogan: Muadzin Istanbul Penakluk Sekulerisme Turki. Pustaka Al-Kautsar.

Taufiq, F. (2020). Post Islamisme: Melihat Turki dalam Persimpangan Agama dan Politik. Relasi Inti Media.

Velasco, A. (2020). Populism and Identity Politics. LSE Public Policy Review, 1(1).

Wahyu, Y. (2021, June 14). Ujian Politik Partai Politik Baru. Harian Kompas.

Wolinetz, S. B. (2002). Beyond the Catch-All Party: Approaches to the study of Parties and Party Organization in Contemporary Democracies. In Political Parties. Old Concepts and New Challenges. Oxford University Press.

Yumitro, G. (2013). Partai Islam dalam Dinamika Demokrasi di Indonesia. Jurnal Ilmu Sosial Dan Ilmu Politik, 17(1). Yuniarto, T. (2019, April 4). Partai Keadilan Sejahtera: Dari Dakwah menuju Parlemen. Harian Kompas. 